\title{
Hubungan Kecemasan Matematis dan Komunikasi Matematis Peserta Didik Kelas X MIPA SMAN 1 Rumbio Jaya
}

\author{
Isra Hidayati ${ }^{1}$, Armiati $^{2}$ \\ ${ }^{1,2}$ Program Magister Pendidikan Matematika, FMIPA Universitas Negeri Padang, \\ Jl. Prof. Dr. Hamka, Air Tawar, Padang, 25111, Indonesia \\ israhidayati28@gmail.com
}

\begin{abstract}
Mathematical communication is one of the important skills that every student must have. But reality students' mathematical communication skills still cannot be said to be good. One of the factors causing the low mathematical communication skills of students is mathematical anxiety. This study aims to determine the relationship between mathematical anxiety and mathematical communication of class X MIPA students at SMAN 1 Rumbio Jaya. This research is quantitative research with correlational research method. The population in this study were students of class X MIPA SMAN 1 Rumbio Jaya and the sample was 37 students from a total of 60 students of class X MIPA SMAN 1 Rumbio Jaya. The research instrument used a mathematical communication skill question and a mathematical anxiety questionnaire. The results showed that mathematical anxiety had a significant relationship with mathematical communication skills. It is known from the value of $r=-0.381$ and $p=0.020<0.05$, meaning that there is a significant negative relationship between mathematical anxiety and mathematical communication skills. The higher the students' mathematical anxiety, the lower the students' mathematical communication skills, and vice versa, the lower the students' mathematical anxiety, the higher the students' mathematical communication skills.
\end{abstract}

Keywords: Mathematical communication, mathematical anxiety

\begin{abstract}
Abstrak
Komunikasi matematis merupakan salah satu kemampuan penting yang harus dimiliki oleh setiap peserta didik. Namun pada kenyataannya kemampuan komunikasi matematis peserta didik masih belum bisa dikatakan baik. Salah satu yang menjadi faktor penyebab rendahnya kemampuan komunikasi matematis peserta didik adalah kecemasan matematis. Tujuan dari penelitian ini adalah untuk mengetahui hubungan antara kecemasan matematis dan komunikasi matematis peserta didik kelas X MIPA SMAN 1 Rumbio Jaya. Penelitian ini merupakan penelitian kuantitatif dengan metode penelitian korelasional. Populasi pada penelitian ini adalah peserta didik kelas X MIPA SMAN 1 Rumbio Jaya dan sampelnya adalah 37 orang peserta didik dari jumlah 60 peserta didik kelas X MIPA SMAN 1 Rumbio Jaya. Instrumen penelitian menggunakan soal kemampuan komunikasi matematis dan angket kecemasan matematis. Hasil penelitian menunjukkan bahwa kecemasan matematis memiliki hubungan signifikan dengan kemampuan komunikasi matematis. Hal ini diketahui dari nilai $r=-0,381$ dan $p=0,020<0,05$, artinya terdapat hubungan signifikan yang negatif antara kecemasan matematis dengan kemampuan komunikasi matematis. Semakin tinggi kecemasan matematis peserta didik maka semakin rendah kemampuan komunikasi matematis peserta didik, begitu pula sebaliknya semakin rendah kecemasan matematis peserta didik maka semakin tinggi kemampuan komunikasi matematis peserta didik.
\end{abstract}

Kata kunci: Kecemasan matematis, komunikasi matematis

Copyright (c) 2021 Isra Hidayati, Armiati

$\triangle$ Corresponding author: Armiati

Email Address: armiati@fmipa.unp.ac.id (Jl. Parak Kerakah, RT 02, RW 01, No. 1 Kec. Pauh, Padang)

Received 28 September 2021, Accepted 13 October 2021, Published 13 December 2021

\section{PENDAHULUAN}

Matematika merupakan salah satu matapelajaran yang berkontribusi dalam banyak segi kehidupan, salah satunya adalah dalam berkomunikasi. Untuk berkomunikasi seseorang memerlukan bahasa, karenanya matematika selain sebagai ilmu juga merupakan bahasa. Melalui Permendikbud No. 59 Tahun 2014, dijelaskan bahwa kemampuan komunikasi merupakan salah satu tujuan diberikannya pembelajaran matematika pada peserta didik. Komunikasi juga merupakan salah satu kompetensi dasar dalam pembelajaran matematika menurut NCTM (Van de Walle, 2008). 
Dalam Permendikbud No. 59 Tahun 2014 disebutkan bahwa kemampuan komunikasi matematika adalah kemampuan peserta didik dalam mengkomunikasikan ide/gagasan, penalaran, serta mampu menyusun bukti matematika dengan menggunakan kalimat lengkap, symbol, tabel, diagram, atau media lain untuk memperjelas keadaan atau masalah (Kemdikbud, 2014). Senada dengan hal ini Lestari \& Mokhammad (2018) menyebutkan kemampuan komunikasi matematis adalah kemampuan menyampaikan gagasan/ ide matematis, baik secara lisan maupun tulisan serta kemampuan memahami dan menerima gagasan/ ide matematis orang lain secara cermat, analisis, kritis, dan evaluatif untuk mempertajam pemahaman.

Oleh sebab itu, kemampuan komunikasi matematis merupakan salah satu kemampuan yang harus dimiliki oleh peserta didik dan dilatihkan oleh pendidik. Namun berdasarkan beberapa hasil penelitian, kemampuan komunikasi peserta didik masih tergolong kurang baik. Penelitian yang dilakukan oleh Asuro \& Fitri (2020), mengungkapkan bahwa peserta didik kelas XI MIPA 2 SMAN 1 Kampar belum memiliki kemampuan komunikasi yang baik. Sejalan dengan hal tersebut, penelitian yang dilakukan oleh Maharani \& Ramlah (2021) juga menunjukkan bahwa kemampuan komunikasi matematis peserta didik masih tergolong rendah.

Kemampuan komunikasi matematis dapat tercapai jika dalam pembelajaran matematika tidak menemui berbagai permasalahan. Namun pada kenyataannya, ada beberapa faktor yang dapat mempengaruhi kemampuan matematis yang secara sifnifikan juga mempengaruhi prestasi peserta didik. Salah satu faktor tersebut adalah kecemasan matematika (Santri, 2017). Hal ini muncul dikarenakan matematika dianggap sebagai pelajaran yang sulit, karena karakteristik matematika yang bersifat abstrak, logis, sistematis dan penuh dengan lambang dan rumus yang membingungkan. Aschraft dan Moore menyebutkan bahwa kecemasan matematis merupakan suatu kondisi yang meliputi emosi rasa takut, ketegangan, dan ketidaknyamanan yang dirasakan oleh beberapa individu dalam situasi yang melibatkan matematika dan dapat mengganggu kinerja tugas matematika seseorang (Putri, 2020).

Beberapa penelitian terdahulu telah banyak menemukan dampak-dampak negatif dari kecemasan matematika terhadap pembelajaran matematika itu sendiri, diantaranya adalah penelitian yang dilakukan oleh Juliyanti \& Pujiastuti (2020), diperoleh bahwa kecemasan matematis memberikan pengaruh yang signifikan terhadap hasil belajar matematika peserta didik secara parsial, yang artinya jika peserta didik ingin mendapatkan hasil belajar yang tinggi maka peserta didik harus menekan atau mengendalikan kecemasannya. Hal ini sejalan dengan penelitian yang dilakukan oleh Setiadi (2018), semakin tinggi kecemasan seorang mahasiswa maka akan ada kecenderungan prestasi belajar mahasiswa tersebut menurun. Penelitian yang dilakukan oleh Disai et al (2018) juga menunjukkan adanya hubungan yang signifikan antara kecemasan matematis dan hasil belajar matematika.

Masih banyak peserta didik yang memiliki kecemasan dalam belajar matematika, dimana peserta didik akan merasakan kegelisahan, kesulitan, serta ketakukan saat akan menghadapi atau 
sedang belajar matematika. Jika hal ini terus berlanjut, maka ada kemungkinan kecemasan dapat mendominasi pikiran peserta didik, yang mengakibatkan peserta didik kesulitan berkonsentrasi saat belajar matematika. Pada penelitian sebelumnya telah dilakukan pengkajian terhadap pengaruh kecemasan pada hasil belajar matematika secara umum. Hasil belajar matematika mencakup berbagai hal, antara lain pemahaman konsep, penalaran matematis, pemecahan masalah dan komunikasi matematis. Kemampuan komunikasi matematis merupakan salah satu kemampuan yang akan berkontribusi dalam banyak kegiatan peserta didik, baik dalam belajar matematika maupun dalam kehidupannya, maka peneliti tertarik untuk mengetahui apakah kecemasan matematis peserta didik memiliki hubungan dengan kemampuan komunikasi matematis. Dengan mengetahui hubungan ini maka pendidik akan dapat merencanakan pembelajaran matematika yang dapat mengurangi dampak kecemasan tersebut. Untuk itu telah dilakukan penelitian kepada pada peserta didik kelas X SMA dengan rumusan masalah yaitu apakah terdapat hubungan antara kecemasan matematis dan kemampuan komunikasi matematis peserta didik kelas X MIPA SMAN 1 Rumbio Jaya?.

\section{METODE}

Metode penelitian yang digunakan dalam penelitian ini adalah metode korelasi dengan pendekatan kuantitatif. Penelitian korelasi bertujuan untuk mengkaji tingkat keterkaitan antar dua variabel atau lebih (Sani, 2018) dan pendekatan kuantitatif digunakan dengan tujuan untuk menguji hipotesis yang telah ditetapkan (Sugiyono, 2015). Sesuai rumusan masalah maka hipotesis yang akan diuji dalam penelitian ini adalah "terdapat hubungan yang berarti antara kecemasan matematis dengan kemampuan matematis peserta didik kelas X SMAN 1 Rumbio Jaya”. Populasi dalam penelitian ini adalah peserta didik kelas X MIPA SMAN 1 Rumbio Jaya Semester Genap Tahun Pelajaran 2020/2021 dan sampelnya adalah 37 peserta didik dari total 60 peserta didik kelas X MIPA SMAN 1 Rumbio Jaya. Sample dipilih dengan menggunakan teknik simple random sampling, yaitu pengambilan anggota sampel dari populasi dilakukan secara acak tanpa memperhatikan srata yang ada dalam populasi (Lestari \& Mokhammad, 2018)

Instrumen dalam penelitian berupa tes terkait kemampuan komunikasi matematis dan angket kecemasan matematika. Soal kemampuan komunikasi matematis disusun berdasarkan indikator yang dikemukakan oleh Kementrian Pendidikan Ontario, yaitu written text, drawing dan mathematical expressions. Angket kecemasan matematis yang digunakan dalam penelitian ini adalah modifikasi angket kecemasan matematis yang disusun oleh Nursilawati (2010). Sebelum diberikan kepada peserta didik instrumen divalidasi untuk mengetahui kualitasnya. Untuk menjawab rumusan masalah Teknik analisis data dilakukan menggunakan korelasi pearson product moment. Korelasi pearson product moment digunakan untuk melukiskan hubungan antara dua buah variabel (Sudaryono, 2021).

\section{HASIL DAN DISKUSI}

Hasil penelitian yang dipaparkan berupa tingkat kecemasan matematis peserta didik, tingkat 
kemampuan komunikasi peserta didik, serta hubungan antara kecemasan matematis dan kemampuan komunikasi matematis peserta didik.

\section{Tingkat Kecemasan Matematis}

Angket kecemasan matematis diberikan kepada 37 sampel dan berisi 26 butir pernyataan (15 pernyataan positif dan 11 pernyataan negatif) yang memuat komponen-komponen untuk mengukur tingkat kecemasan peserta didik, diantaranya adalah komponen mood, komponen motorik, komponen kognitif, dan komponen somatik. Data angket diolah dengan menggunakan bantuan program Ms. Excell 2019. Data yang diperoleh dari hasil angket kecemasan matematis dikelompokkan kedalam beberapa tingkatan kecemasan menurut Stuart dan Laraia, yaitu kecemasang ringan, kecemasan sedang, kecemasan berat dan panik (Hardiyati, 2020).

Tabel 1. Tingkat Kecemasan Matematis Peserta Didik Kelas X MIPA SMAN 1 Rumbio Jaya

\begin{tabular}{|c|c|c|c|}
\hline No & Tingkat Kecemasan & Frekuensi & Presentase (\%) \\
\hline 1 & Ringan & - & - \\
\hline 2 & Sedang & 16 & 43,24 \\
\hline 3 & Berat & 19 & 51,35 \\
\hline 4 & Panik & 2 & 5,41 \\
\hline \multicolumn{2}{|r|}{ Jumlah } & 37 & 100 \\
\hline
\end{tabular}

Tabel 1 menunjukkan bahwa siswa dengan kecemasan sedang sebanyak 16 orang, tingkat kecemasan berat sebanyak 19 orang, dan tingkat panik sebanyak 2 orang. Secara keseluruhan, jumlah peserta didik kelas X MIPA SMAN 1 Rumbio Jaya yang memiliki kecemasan berat lebih banyak dari tingkat kecemasan lainnya.

\section{Kemampuan Komunikasi Matematis}

Kemampuan komunikasi matematis peserta didik dalam penelitian ini diukur dengan menggunakan tes kemampuan komunikasi matematis. Tes yang diberikan berupa tiga soal uraian materi trigonometri yang telah divalidasikan. Masing-masing soal mewakili masing-masing indikator kemampuan komunikasi yaitu written text, drawing, dan mathematical expressions. Data hasil tes kemampuan komunikasi matematis peserta didik di olah dengan menggunakan Ms. Excel 2019. Data yang diperoleh dari hasil tes kemampuan komunikasi matematis dikelompokkan kedalam beberapa kategori menurut pengkategorian oleh Ngalim Purwanto (Purwanto, 1988), yang disajikan pada tabel 2 berikut:

Tabel 2. Kategori Kemampuan Komunikasi Matematis

\begin{tabular}{|c|c|}
\hline Persentase & Predikat \\
\hline $86-100 \%$ & Sangat Baik \\
\hline $76-85 \%$ & Baik \\
\hline $60-75 \%$ & Cukup \\
\hline $55-60 \%$ & Kurang \\
\hline$\leq 54 \%$ & Kurang Sekali \\
\hline
\end{tabular}


Hubungan Kecemasan Matematis dan Komunikasi Matematis Peserta Didik Kelas X MIPA SMAN 1 Rumbio Jaya, Isra

Tabel 3. Tingkat Kemampuan Komunikasi Matematis Peserta Didik Kelas X MIPA SMAN 1 Rumbio

\begin{tabular}{|c|c|c|c|}
\hline \multirow{2}{*}{ No } & $\begin{array}{c}\text { Tingkat Kemampuan Komunikasi } \\
\text { Matematis }\end{array}$ & Frekuensi & Persentase (\%) \\
\hline 1 & Sangat Baik & 5 & 13,51 \\
\hline 2 & Baik & 3 & 8,11 \\
\hline 3 & Cukup & 8 & 21,62 \\
\hline 4 & Kurang & 2 & 5,41 \\
\hline 5 & Kurang Sekali & 19 & 51,35 \\
\hline & Jumlah & 37 & 100 \\
\hline
\end{tabular}

Dapat dilihat pada tabel 3 bahwa peserta didik dengan kemampuan komunikasi matematis sangat baik sebanyak 5 orang, peserta didik dengan kemampuan komunikasi matematis baik sebanyak 3 orang, peserta didik dengan kemampuan komunikasi matematis cukup sebanyak 8 orang, peserta didik dengan kemampuan komunikasi matematis kurang sebanyak 2 orang, dan peserta didik dengan kemampuan komunikasi matematis kurang sekali sebanyak 19 orang. Secara keseluruhan, kemampuan komunikasi matematis peserta didik kelas X MIPA SMAN 1 Rumbio Jaya yang memiliki kemampuan komunikasi matematis kurang sekali lebih banyak dibandingkan tingkatan kemampuan komunikasi matematis lainnya.

\section{Hubungan Kecemasan Matematis dan Kemampuan Komunikasi Matematis}

Analisis data untuk mengetahui hubungan antara kecemasan matematis dan kemampuan komunikasi matematis dilakukan dengan menggunakan SPSS 22 dengan menggunakan korelasi Pearson dan hipotesisnya adalah:

$\mathrm{H}_{\mathrm{O}} \quad$ : Tidak ada hubungan antara kecemasan matematis dan kemampuan komunikasi matematis peserta didik kelas X MIPA SMAN 1 Rumbio Jaya.

$\mathrm{H}_{1}$ : Ada hubungan antara kecemasan matematis dan kemampuan komunikasi matematis peserta didik kelas X MIPA SMAN 1 Rumbio Jaya.

Tabel 4. Output Uji Normalitas

\begin{tabular}{|l|r|r|r|r|r|r|}
\hline & \multicolumn{3}{|c|}{ Kolmogorov-Smirnova $^{\text {a }}$} & \multicolumn{3}{c|}{ Shapiro-Wilk } \\
\cline { 2 - 7 } & Statistic & \multicolumn{1}{c|}{ Df } & \multicolumn{1}{c|}{ Sig. } & \multicolumn{1}{c|}{ Statistic } & \multicolumn{1}{c|}{ Df } & \multicolumn{1}{c|}{ Sig. } \\
\hline Kecemasan Matematis & .095 & 37 & .200 & .967 & 37 & .340 \\
\hline $\begin{array}{l}\text { Kemampuan Komunikasi } \\
\text { Matematis }\end{array}$ & .140 & 37 & .067 & .948 & 37 & .082 \\
\hline
\end{tabular}

Pada tabel 4 memperlihatkan nilai signifikan yang tertera pada kolom Kolmogorov - Smirnov sebesar 0,200 untuk kecemasan matematis dan 0,067 untuk kemampuan komunikasi matematis. Karena nilai signifikan masing-masing data lebih besar dari nilai $\alpha(0,05)$ maka masing-masing data tersebut berdistribusi normal. 
Tabel 5. Output Uji Linearitas

\begin{tabular}{|c|c|c|c|c|c|c|c|}
\hline & & & $\begin{array}{c}\text { Sum of } \\
\text { Squares }\end{array}$ & df & $\begin{array}{l}\text { Mean } \\
\text { Square }\end{array}$ & $\mathrm{F}$ & Sig. \\
\hline \multirow{5}{*}{$\begin{array}{l}\text { Komunikasi } \\
\text { Matematis* } \\
\text { Kecemasan } \\
\text { Matematis }\end{array}$} & \multirow{3}{*}{$\begin{array}{l}\text { Between } \\
\text { Groups }\end{array}$} & (Combined) & 317.354 & 23 & 13.798 & 1.330 & .302 \\
\hline & & Linearity & 65.617 & 1 & 65.617 & 6.323 & .026 \\
\hline & & $\begin{array}{l}\text { Deviation } \\
\text { from } \\
\text { Linearity }\end{array}$ & 251.736 & 22 & 11.443 & 1.103 & .440 \\
\hline & Within Groups & & 134.917 & 13 & 10.378 & & \\
\hline & Total & & 452.270 & 36 & & & \\
\hline
\end{tabular}

Tabel 5 memperlihatkan nilai signifikan yang dihasilkan sebesar 0,440. Karena nilai signifikan Deviation from Linearity lebih besar dari nilai $\alpha(0,05)$ maka data tersebut memiliki hubungan yang linear.

Tabel 6. Output Uji Korelasi Kecemasan Matematis dan Kemampuan Komunikasi Matematis Peserta Didik

\begin{tabular}{|l|l|r|r|}
\hline \multicolumn{2}{|c|}{} & \multicolumn{1}{|c|}{$\begin{array}{c}\text { Kecemasan } \\
\text { Matematis }\end{array}$} & \multicolumn{1}{c|}{$\begin{array}{c}\text { Komunikasi } \\
\text { Matematis }\end{array}$} \\
\hline \multirow{2}{*}{$\begin{array}{l}\text { Kecemasan } \\
\text { Matematis }\end{array}$} & Pearson Correlation & 1 & $-.381^{*}$ \\
\cline { 2 - 4 } & Sig. (2-tailed) & 37 & .020 \\
\cline { 2 - 4 } & $\mathrm{N}$ & $-.381^{*}$ & 37 \\
\hline \multirow{2}{*}{$\begin{array}{l}\text { Komunikasi } \\
\text { Matematis }\end{array}$} & Pearson Correlation & .020 & 37 \\
\cline { 2 - 4 } & Sig. (2-tailed) & 37 & 37 \\
\cline { 2 - 4 } & $\mathrm{N}$ & & \\
\hline
\end{tabular}

Berdasarkan hasil uji korelasi dengan menggunakan korelasi Pearson pada tabel 6, diketahui bahwa kecemasan matematis memiliki hubungan signifikan dengan kemampuan komunikasi matematis. Hal ini diketahui dari nilai $r=-0,381$ dan $p=0,020<0,05$, dengan demikian $\mathrm{H}_{\mathrm{O}}$ ditolak, artinya terdapat hubungan signifikan yang negatif antara kecemasan matematis dengan kemampuan komunikasi matematis. Semakin tinggi kecemasan matematis peserta didik maka semakin rendah kemampuan komunikasi matematis peserta didik, begitu pula sebaliknya semakin rendah kecemasan matematis peserta didik maka semakin tinggi kemampuan komunikasi matematis peserta didik.

Tabel 7. Kemampuan Komunikasi Matematis Peserta Didik Berdasarkan Tingkat Kecemasan Matematis Peserta Didik

\begin{tabular}{|c|c|c|c|c|c|c|}
\hline \multirow{2}{*}{$\begin{array}{c}\text { Kategori } \\
\text { Kecemasan }\end{array}$} & \multicolumn{6}{|c|}{ Indikator Kemampuan Komunikasi Matematis } \\
\cline { 2 - 7 } & \multicolumn{2}{|c|}{ Written Text } & \multicolumn{2}{|c|}{ Drawing } & \multicolumn{2}{c|}{ Mathematical Expressions } \\
\cline { 2 - 7 } & $\bar{x}$ & $\%$ & $\bar{x}$ & $\%$ & $\bar{x}$ & - \\
\hline $\begin{array}{c}\text { Ringan/ } \\
\text { Rendah }\end{array}$ & - & - & - & - & - & 53,25 \\
\hline Sedang & 2,69 & 67,25 & 2,88 & 72,00 & 2,13 & 31,50 \\
\hline Berat/ Tinggi & 1,89 & 47,25 & 2,11 & 52,75 & 1,26 & 12,50 \\
\hline $\begin{array}{c}\text { Panik / Sangat } \\
\text { Tinggi }\end{array}$ & 2,00 & 50,00 & 1,00 & 25,00 & 0,50 & \\
\hline
\end{tabular}


Pada tabel 7, dapat dilihat bahwa peserta didik dengan kecemasan matematis sedang memiliki nilai rata-rata paling rendah pada indikator Mathematical Expressions dengan rata-rata 2,13 dari skor maksimal 4, begitu juga dengan peserta didik pada dengan kecemasan berat dan panik dengan ratarata masing masing adalah 1,26 dan 0,50. Hal ini menunjukkan bahwa peserta didik kelas X MIPA SMAN 1 Rumbio Jaya memiliki kemampuan yang lemah dalam mengekspresikan suatu konsep matematika dengan menyatakan peristiwa dalam kehidupan sehari-hari dalam bahasa atau simbol matematika. Peserta didik dengan kecemasan sedang dan kecemasan panik memiliki kemampuan lebih baik pada indikator Written Text dibandingkan dengan indikator lainnya dengan nilai rata-rata masing-masingnya adalah 2,69 dan 2,00. Sedangkan peserta didik dengan kecemasan berat memiliki kemampuan lebih baik pada indikator Drawing dibandingkan dengan indikator Written Text dan Mathematical Expressions dengan rata-rata sebesar 2,11.

Berdasarkan hasil analisis statistik menunjukkan bahwa kecemasan matematis memiliki hubungan negatif dengan komunikasi matematis peserta didik, yang artinya semakin tinggi kecemasan matematis peserta didik maka semakin rendah kemampuan komunikasi matematisnya dan sebaliknya semakin rendah kecemasan matematis peserta didik maka semakin tinggi kemampuan komunikasi matematisnya. Hal ini didukung oleh temuan Namkung et al., (2019) dimana terdapat hubungan negatif yang signifikan antara kecemasan matematis dan kinerja matematika. Hal ini menunjukkan bahwa kecemasan ternyata dapat mempengaruhi prestasi belajar peserta didik. Hal ini juga diperkuat oleh hasil penelitian-penelitian terdahulu yang menemukan adanya hubungan negatif antara kecemasan matematis dan prestasi belajar peserta didik yaitu penelitian yang dilakukan oleh Setiadi (2018) dan Disai et al., (2018) yang menunjukkan adanya hubungan negatif antara kecemasan matematis dan prestasi belajar peserta didik. Temuan dalam penelitian ini juga sejalan dengan penelitian terdahulu yang dilakukan oleh Somawati (2016), yang menunjukkan bahwa terdapat pengaruh langsung antara kecemasan belajar peserta didik dengan kemampuan komunikasi matematis peserta didik.

Mengenai adanya hubungan negatif antara kecemasan matematis dan kemampuan komunikasi matematis, maka untuk meningkatkan kemampuan komunikasi matematis peserta didik, salah satu yang dapat dicoba adalah dengan menciptakan suasana belajar yang menyenangkan sehingga peserta didik dapat merasa tenang dan rileks dalam belajar matematika. Pembelajaran yang tidak terpusat hanya kepada guru, sehingga peserta didik merasa dilibatkan dan dianggap penting dalam proses pembelajaran juga dapat menjadi alternatif untuk menciptakan kondisi belajar yang kondusif (Sakarti, 2018).

\section{KESIMPULAN}

Kesimpulan yang dapat diambil melalui penelitian ini adalah terdapat hubungan signifikan yang negatif antara kecemasan matematis dan kemampuan komunikasi matematis peserta didik kelas $\mathrm{X}$ MIPA SMAN 1 Rumbio Jaya. Hal ini berarti semakin tinggi kecemasan matematis peserta didik maka 
semakin rendah kemampuan komunikasi matematis peserta didik, begitu pula sebaliknya semakin rendah kecemasan matematis peserta didik maka semakin tinggi kemampuan komunikasi matematis peserta didik. Penelitian mendatang perlu dilakukan untuk mengkaji penyebab kecemasan matematis yang dimiliki oleh peserta didik untuk kemudian dapat ditemukan solusi yang tepat untuk dapat menurunkan kecemasan matematis peserta didik.

\section{UCAPAN TERIMA KASIH}

Segala puji bagi Allah SWT. Peneliti ucapkan banyak terima kasih kepada semua pihak yang telah membantu terlaksananya penelitian ini. Terima kasih kepada orang tua peneliti yang terus mendukung dan mendoakan peneliti. Terima kasih kepada Kepala Sekolah SMAN Rumbio Jaya yang telah memberikan izin untuk melakukan penelitian dan kepada seluruh guru-guru di SMAN 1 Rumbio Jaya. Terima kasih kepada dosen pembimbing ibu Dr. Armiati, M.Pd yang telah memberikan arahan dan bimbingan dalam penelitian ini.

\section{REFERENSI}

Asuro, N., \& Fitri, I. (2020). Analisis Kemampuan Komunikasi Matematis Ditinjau dari Self ConceptSiswa SMA/MA. Suska Journal of Mathematics Education, 6(1), 33-46.

Disai, W. I., Dariyo, A., \& Basaria, D. (2018). Hubungan Antara Kecemasan Matematika Dan SelfEfficacy Dengan Hasil Belajar Matematika Siswa Sma X Kota Palangka Raya. Jurnal Muara Ilmu Sosial, Humaniora, Dan Seni, 1(2), 556-568.

Hardiyati. (2020). Kecemasan Saat Pandemi Covid-19. Gowa: Jariah Publishing Intermedia.

Hendriana, H., Rohaeti, E. E., \& Sumarmo, U. (2018). Hard Skills dan Soft Skills Matematik Peserta didik. Bandung: Refika Aditama.

Indonesia, M. P. dan K. R. (2014). Peraturan Menteri Pendidikan dan Kebudayaan Republik Indonesia Nomor 59 Tahun 2014 tentang Kurikulum 2013 Sekolah Menengah Atas/ Madrasah Aliyah. Departemen Pendidikan Nasional.

Juliyanti, A., \& Pujiastuti, H. (2020). Terhadap Hasil Belajar Matematika Siswa. Prima: Jurnal Pendidikan Matematika, 4(2), 75-83.

Lestari, K. E., \& Mokhammad, R. (2018). Penelitian Pendidikan Matematika. Bandung: Refika Aditama.

Maharani, D., \& Ramlah. (2021). Deskripsi Kemampuan Komunikasi Matematis Siswa dalam Menyelesaikan Permasalahan Segitiga dan Segiempat. 4(2), 287-294.

Namkung, J. M., Peng, P., \& Lin, X. (2019). The Relation Between Mathematics Anxiety and Mathematics Performance Among School-Aged Students: A Meta-Analysis. Review of Educational Research, 89(3), 1-38.

Nursilawati. (2010). Hubungan Self-Efficacy Matematika dengan Kecemasan Menghadapi Pelajaran Matematika [Universitas Islam Negeri Syarif Hidayatullah].

Purwanto, N. (1988). Prinsip-Prinsip dan Teknik Evaluasi Pengajaran. Bandung: Remadja Karya.

Putri, H. E. (2020). Kemampuan-Kemampuan Matematis dan Pengembangan Instrumennya. 
Hubungan Kecemasan Matematis dan Komunikasi Matematis Peserta Didik Kelas X MIPA SMAN 1 Rumbio Jaya, Isra Hidayati, Armiati

Bandung: Sumedang Press.

Sakarti, H. (2018). Hubungan Kecemasan dan Kemampuan Siswa dalam Menyelesaikan Masalah Matematika. Jurnal Pendidikan Informatika Dan Sains (JPIS), 7(1), 28-41.

Sani, R. A. (2018). Penelitian Pendidikan. Jakarta: Tira Smart.

Santri, F. S. (2017). Ada Apa Dengan Kecemasan Matematika? Journal of Medives, 1(1), 59-65.

Setiadi, Y. (2018). Hubungan Konsep Diri, Kecerdasan Emosional, dan Kecemasan Belajar dengan Prestasi Belajar Mahasiswa. JNPM (Jurnal Nasional Pendidikan Matematika), 2(1), 119-132.

Somawati, S. (2016). Pengaruh Kecemasan Dan Kemandirian Belajar Terhadap Kemampuan Komunikasi Matematika Siswa Sma Negeri Di Kecamatan Pasar Rebo. Research and Development Journal of Education, 3(1), 35-51.

Sudaryono. (2021). Statistik I (Statistik Deskriptif untuk Penelitian). Yogyakarta: Andi.

Sugiyono. (2015). Metode Penelitian Pendidikan. Bandung: Alfabeta.

Van de Walle, J. A. (2008). Matematika Sekolah Dasar dan Menengah. Jakarta: Erlangga. 